\title{
DEFENSIVE STRATAGEMS OF PLANTS, WITH SPECIAL REFERENCE TO ALLELOPATHY
}

\author{
by J.V. Lovett
}

(with three tables and two text-figures)

\begin{abstract}
LOVETT, J.V., 1985 (3l:vii): Defensive stratagems of plants, with special reference to allelopathy. Pap. Proc. $R$. Soc. Tasm. 119:31-37. https://doi.org/10.26749/rstpp.119.31 ISSN 0080-4703. Department of Agricultural Science, University of Tasmania, Hobart, Tasmania, Australia, 7005.

The green plant has evolved an array of defences to ameliorate the effects of stresses in its environment. Allelopathy, biochemicalinteractions between plants, plays a role in plant defence but recent work suggests that some compounds which act as allelochemicals may also be effective in the defence of plants against other organisms. Some examples of allelopathy in associations of crop and weed species are discussed in this context. Key Words: allelopathy, trichome, plant defence
\end{abstract}

\section{INTRODUCTION}

The advantage to the green plant of autotrophy is to some extent off set by the disadvantage of a static habit in an often hostile environment.

In the more mobile animal kingdom physical and chemical defences against environmental stresses are well developed and widely recognised. This suggests that an array of defensive ploys by plants will also occur but such ploys have attracted relatively little attention in the literature.

A first line of defence is the plant surface which, although relatively tough, may be damaged by the elements, by pollution, by abrasion and by a variety of organisms. The waxy cuticle of leaf surfaces may act as a primary barrier to attack by a variety of organisms (Cutter 1976) and many leaves also carry trichomes which contribute to the defence of plant surfaces (Levin 1973). Trichomes may, for example, deter insects from landing on leaves or mammals from eating them. Tobacco trichomes are known insect-repellents (Thurston, Smith \& Cooper 1966) whilst other species, such as nettles, have developed the trichome to a high level of defensive sophistication as "syringes" which deliver irritant chemicals when the tip is broken (Fahn 1967). However, whilst the physical significance of structures such as trichomes in a defensive mode has been recognised, the complementary role of plant-produced chemicals has been much less explored.

\section{SECONDARY COMPOUNDS AND PLANT DEFENCE}

Chemicals are frequently employed in the defence of animals (Edmunds 1974) even when physical defences are well developed. Thus, in the Australian turtle genus Chelodina the protection afforded by the shell may be complemented by malodorous fluid when the animal is alarmed (Cogger 1979), whilst in savannah ungulates (Gosling 1980) inter-specific scent communication may assist in the formation of a "defence guild".

In plants, chemicals used in a defensive mode are by-products of primary metabolic pathways and are known, accordingly, as "secondary compounds" (Levin 1976). Amongst the groups of secondary compounds, the phenolics, waxes and terpenes are widely distributed among plant families whilst other groups, for example, the glucosinolates found in the Brassicaceae, are particularly identified with a single family. Although qualitative and, more particularly, quantitative, information on these chemicals is often lacking, they are recognised as widely distributed and normal products of plant metabolism.

\section{ALLELOPATHY}

A field of study in which the role of secondary compounds is currently of considerable interest is allelopathy. The term means, literally, "mutual harm", and it has been applied in this sense to negative, or inhibitory, chemical interactions between plants. However, depending on concentration, allelochemicals may stimulate biological responses (Lovett 1982a). Thus, Molisch (1937) extended the term "allelopathy" to include all chemical interactions, whether positive or negative, between plants of all levels of complexity. This broader definition has gained wide acceptance and more recently (Lovett 1982a, 1983a) it has been recognised that chemicals studied in the context of 
Aspects of three case studies are presented to illustrate the range and complexity of allelopathy, as demonstrated by weeds and in the context of defensive strategems.

\section{The association of Camelina sativa (L.) Crantz and Linum usitatissimum L. (linseed)}

Camelina sativa (Brassicaceae) has been recorded as a weed of cultivation in Western Australia, South Australia, Victoria and Tasmania (Hewson 1982). It is better known as a weed of Linum usitatissimum (Linaceae), linseed, in European cropping systems where work of Grümmer and Beyer (1960) indicated that the yield of linseed could be significantly reduced in the presence of Camelina spp. in the field if rain fell at a critical time of the year. Rain washed chemicals from the leaves of the weed onto the leaves of the crop, promoting the phytotoxic effect. Although this report aroused considerable interest, like ma ny other instances of allelopathy further investiga tions were neglected. Thus, the chemical, or chemicals, concerned were not identified nor was the primary mode of action of the weed-produced chemical on the crop plant elucidated.

Through a series of experiments commenced in 1977 a more complete understanding of this interaction has been gained (fig. 1).

Under controlled conditions washings of intact foliage of Camelina consistently stimulated the growth of the radicles of germinating linseed seeds. The presence of bacteria in the Camelina phyllosphere was necessary to the stimulatory phenomenon. These were cosmopolitan, gramnegative rods, Enterobacter cloacae (Jordan) Hormaeche \& Edwards (Lovett \& Sagar 1978) or Pseudomonas fluorescens (Trevisan) Migula (Lovett \& Jackson 1980).

Washings of Camelina leaves contain organic acids which sustain rapid bacterial growth. During this growth, complex organic compounds present in the leaves are broken down to simpler compounds at least one of which, benzylamine, is allelopathic (Lovett \& Duffield 1981). Leaf damage may be necessary to the release of the precursor, benzyl isothiocyanate, and as maximum bacterial populations are present in senescent foliage (table 1), maximum allelopathic activity may occur at this stage of the life cycle.

In petri dishes, under controlled conditions, benzylamine at low concentrations stimulated germinating seedlings of linseed in a manner similar to that produced by Camelina leaf washings. Higher concentrations became inhibitory, a response typical of allelochemicals (Lovett 1982a). However, in soil under controlled conditions, even

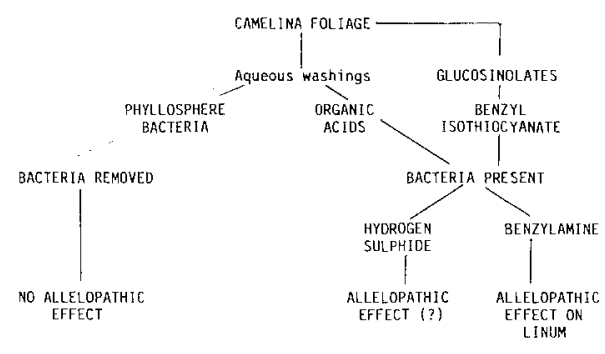

FIG. 1 - Allelopathy in a Camelina sativa, phyllosphere bacteria and Linum usitatissimum association.

allelopathy may play a wider role in the defensive and, possibly, offensive relationships of plants.

In natural plant communities allelochemicals are among the factors which maintain homeostasis (Rabotnov 1981). Many responses to allelochemicals are, therefore, subtle, having developed during evolution of plant communities. Continuing the analogy with animal responses Edmunds (1974) states, in relation to communities of a nimals, “.. there will be much greater selection pressure to evade predation and to evolve highly elaborate anti-predator defences in a stable environment than in an unstable environment".

Allelopathy is a part of "interference", the term used by Harper (1977) to describe changes in the growth rate and form of plants brought about by the influences of neighbouring plants upon the environment. Competition for environmental resources, commonly, light, water and nutrients (Donald 1963), is also a part of interference. Conventional agricultural practise maintains disturbed (unstable) environments with restricted species diversity. In such environments weeds are often able to express their capability to interfere with other plants to a greater extent than occurs in species-rich, stable communities. Thus, competition and allelopathy may become more readily a pparent.

Crop plants tend not to be allelopathically active, especially when highly selected (Lovett 1983b). Where weed and crop species are close relatives the former show the greater allelopathic potential (Lovett, Fraser \& Duffield 1982). Since there is an energy cost to the plant in producing secondary compounds (Levin 1976) it may be that selection for physiological specialisation in the direction of quantity and quality of yield militates against the development of an endogenous chemical defence capability in crop species. Conversely, in weeds, this capability can be better developed without detriment to other attributes. 
Table 1

Bacterial colonies developed from similar volume samples of washings from Camelina foliage after $24 \mathrm{~h}$ incubation (colonies per $9 \mathrm{~cm}$ diameter plate, means of four replicates).

\begin{tabular}{lcccc}
\hline & $\begin{array}{c}\text { Senescent } \\
\text { leaves }\end{array}$ & $\begin{array}{c}\text { Green } \\
\text { leaves }\end{array}$ & $\begin{array}{c}\text { Flowers/immature } \\
\text { capsules }\end{array}$ & Stalks \\
\hline Number of colonies & $854^{\mathrm{a}}$ & $7.0^{\mathrm{b}}$ & $5.3^{\mathrm{b}}$ & $0.75^{\mathrm{c}}$ \\
\hline
\end{tabular}

Means which are identified by the same letter are not significantly different at the $5 \%$ level, Studentized Range Test. (After Lovett 1982b).

low concentrations of benzylamine proved to be inhibitory to germinating linseed (table 2). It seems likely that the more complete and sustained contact between seed and soil compared with seed and filter paper in a petri dish leads to a greater uptake of benzylamine with consequent inhibition rather than stimulation.

Transmission electron microscopy (TEM) has indicated disruption of cellular membranes and suggests that the primary cause of reduction in early growth of linseed seedlings is a reduced ability to metabolise food reserves (Lovett $1982 \mathrm{~b}$ ). Such fundamental disruption could be significant at other growth stages where metabolic activity is high, for example, seed filling. In addition, it has been observed that benzylamine creates hydrophobic conditions in soil, possibly inhibiting uptake of water by plants (Lovett 1982b)

In this particular example the definition of allelopathy by Molisch (1937) is amply justified through the combination of a bacterium modifying a chemical exudate from one higher plant to a form which becomes potentially phytotoxic to a second higher plant.

The involvement of bacteria as intermediate organisms in promoting allelopathy appears to be unique in the literature. Other organisms may, however, play a complementa ry role. For example, Trenbath and Fox (1976) have suggested that phytophagous insects concentrate allelochemicals produced by leaves of Eucalyptus globulus s.sp. bicostata (Maiden et al.) Kirkp. Whilst aqueous washings of E. globulus leaves slightly encouraged germination of sensitive pasture species in their experiments, insect droppings, in which allelochemicals were concentrated, became inhibitory. These findings parallel our experience with bacteria in the Camelina/linseed system.

In correlating these observations with the data of Grummer and Beyer (1960) the importance of water in allelopathic systems becomes apparent. In their experiments rainfall in the field at a critical time of year was necessary to the allelopathic manifestations and our data suggest that this time corresponds to the maximum release of substrate by the weed and, perhaps, to particular vulnerability of the receiving crop.

\section{The association of Datura stramonium $\mathbf{L}$. and Helianthus annuus L. (sunflower)}

Whittaker (1970) states that alkaloids are".. evolutionary expressions of quiet antagonism of a

Table 2

Effects of benzylamine on early growth in soil of Linum usitatissimum (means of ten replicates).

\begin{tabular}{lcccccc}
\hline & $\begin{array}{c}\text { Days after } \\
\text { Sowing }\end{array}$ & $\mathbf{0}$ & $\mathbf{1 0}$ & $\mathbf{1 0 0}$ & $\mathbf{1 0 0 0}$ & $\mathbf{P}$ \\
\hline Rariables & 8 & $167.0^{\mathrm{a}}$ & $148.8^{\mathrm{ab}}$ & $137.9^{\mathrm{b}}$ & $108.0^{\mathrm{c}}$ & $<0.001$ \\
Shoot height $(\mathrm{mm})$ & 7 & $23.4^{\mathrm{f}}$ & $23.1^{\mathrm{f}}$ & $21.4^{\mathrm{g}}$ & $20.7^{\mathrm{g}}$ & $<0.01$ \\
\hline
\end{tabular}

Means which are identified by the same letter are not significantly different at the $5 \%$ level, Studentized Range Test. (After Lovett and Levitt 1981). 
plant to its enemies". However, whilst many studies have been made of the effects of alkaloids upon mammals, including humans, there is a dearth of information as to the effects of alkaloids produced by plants upon other plants.

The family Solanaceae is particularly associated with alkaloid formation, many species having a history of use in pharmacy and other purposes. Datura stramonium is an important weed member of the family, present in all Australian States (Purdie, Symon \& Haegi 1982), which adversely affects the growth of, particularly irrigated summer crops in areas such as northwestern New South Wales (Felton 1979). Datura is known to contain a number of alkaloids, principally scopola mine and hyoscyamine (Mothes 1955). These are translocated from the site of synthesis in the roots to accumulate in the leaves and seeds (Cromwell 1944, Dawson 1948). The leaves are unpalatable to stock as a over 35 weeks in lateritic podzolic soil. These effects had both chemical and physical components, with the moisture status of the soil influencing the magnitude of the inhibition.

Under field conditions, the phytotoxicity of Datura allelochemicals persisted in lateritic podzolic soil for 15 weeks.

During the course of these experiments a property at Moree (northwestern New South Wales) was visited where an irrigation farmer had experienced three consecutive failures with different summer crops. The black earth soil on the property had a history of severe infestation by Datura. Thin layer chromatography was used to identify the alkaloids, scopolamine and hyoscyamine, from the soil where they had been present for up to 7 months.

Dormancy is an important factor in dispersal in time of many species of weeds. In Datura, dormancy is broken when alkaloids are leached

Table 3

\section{Relative effects of Datura seed and seed washings} on radicle growth of Helianthus annuus.

\begin{tabular}{lcccc}
\hline Treatment & $\begin{array}{c}\text { Sterile } \\
\text { sand }\end{array}$ & $\begin{array}{c}\text { Sterile loam } \\
\text { plus sand }\end{array}$ & $\begin{array}{c}\text { Mlack earth } \\
\text { soil }\end{array}$ & $\begin{array}{c}\text { Lateritic } \\
\text { podzolic soil }\end{array}$ \\
\hline $\begin{array}{l}\text { Control } \\
\text { (sterile water) }\end{array}$ & 100 & 100 & 100 & \\
Seeds & 68.7 & 76.6 & 84.0 & 100 \\
Seed washings & 52.2 & 28.2 & 70.5 & 57.3 \\
\hline
\end{tabular}

All differences between treatment means, within media, are statistically significant.

consequence of their bitter taste but other implications of the alkaloid content for plant defence have remained unexplored.

The presence of the alkaloids scopolamine and hyoscyamine in aqueous washings of Datura foliage and seeds has been confirmed (Lovett, Levitt, Duffield \& Smith 1981), with washings of seeds containing higher concentrations of the alkaloids. In two sterile media the presence of $4.95 \mathrm{~g}$ Datura seed, the average contents of one seed capsule, in $50 \mathrm{ml}$ sterile water, significantly red uced radicle length of sunflower (table 3). Further studies (Levitt \& Lovett 1984) in which different soil types were used, indicated that the type and amount of clay, the amount of organic matter and the dominant particle size of the soil all modified the allelopathic effect (table 3 ).

Under cont rolled conditions, alkaloids from Datura seeds remained at concentrations which were toxic to germinating seeds of sunflower for from the seed coat. Rain is vital to this process. Following rain, or pre-irrigation, crop seeds adjacent to Datura seeds in the soil are exposed to varying amounts of alkaloid. Further, it has been shown that Datura seedlings have the potential to synthesise alkaloids and to release them into the soil by foliar leaching and by exudation from the roots from as early as the sixth day of germination (James 1946, Mothes 1955). This appears to be an elegant example of a defensive adaptation whereby weed seedlings, during the period of maximum vulnerability, are protected from interference by other plants through chemicals carried in the seed coat, whilst ra pidly developing their own defensive capability.

The primary mode of action of the allelochemicals of Datura is no less sophisticated. A recent survey (Lovett 1982b) has indicated that only about $2 \%$ of studies of allelopathy progress beyond the level of describing gross morphological 
changes. As in the case of Camelina, TEM has indicated disruption of normal cellular metabolism of the target plant. Specifically, the metabolism of starch by the germinating sunflower seed was adversely affected, as evidenced by the accumulation of amyloplasts in the root tips of affected seedlings (Levitt, Lovett \& Garlick 1984). Significantly the allelochemicals of both Camelina and Datura disrupt metabolic processes, thus disadvantaging a competitor, rather than effecting an outright kill. Current developments in the herbicide industry have similar objectives.

\section{The association of Salvia reflexa Hornem and Triticum aestivum L. (wheat)}

Aromatic plants are valued for aesthetic and commercial reasons - aroma may also be an indicator of potential allelopathic activity (Lovett 1979). The family Lamiaceae encompasses many a romatic plants, some of which a re associated with the production of essential oils for commerce and others with the production of volatile growth inhibitors. Members of the genus Salvia have been investigated in this latter context.

Salvia leucophylla Greene, S. apiana Jeps and $S$. mellifera Greene grow naturally in the soft chaparral communities of southern California and contain phytotoxic terpenes which volatilise and inhibit the establishment of seedlings of a wide variety of plants (Muller 1966). The zone of inhibition may extend $8-10$ metres beyond either the lateral spread of the Salvia root system or the shrub crown, favouring the hypothesis that the toxic material released by these plants is volatile. Subsequent analyses revealed the presence of the monoterpenes alpha-pinene, beta-pinene, camphene, cineole and camphor, all of which inhibited the germination and radicle growth of test species. In addition, it was shown that the soil, particularly when dry, acted as a reservoir for the terpenes, accounting for long-term inhibitory effects observed in the field (Muller 1966).

Experiments with $S$. reflexa (mintweed), a weed of cropping areas in New South Wales, Queensland, South Australia and Victoria (Willis 1972) have shown that aromatic substances liberated by whole plants affect the early growth of wheat (Lovett 1982a). Wetting the foliage greatly enhances the scent of $S$. reflexa and aqueous washings of foliage have more pronounced allelopathic effects upon germination and early growth of wheat than do the aromatics alone.

Gas chromatographic analyses of foliage washings have revealed the presence of monoterpenes similar to those previously identified in $S$. leucophylla. Trichomes in the Lamiaceae a re reposi- tories for aromatics, for example, the essential oil of Mentha piperita L. (Clark \& Menary 1980) and in $S$. reflexa it is believed that the terpenes are sequestered in trichomes pending release into the environment (Lovett \& Levitt 1981). Of those identified, cineole is inhibitory to seedling growth of wheat. However, terpenes have low solubility in water and when the terpene fraction is removed from foliage washings a toxic principal, as yet unidentified, remains. The importance of water in promoting allelopathic activity is again apparent.

\section{WIDER IMPLICATIONS OF ALLELO-CHEMICALS IN DEFENCE}

The example of Salvia is, to date, the most significant of those cited in terms of allelopathy as a component of defence manifestations in plants. As discussed, the monoterpenes present in the genus have allelopathic effects against potential plant competitors in managed communities in Australia and in natural plant communities in California. Potts and Lovett (unpublished data) have recently identified alpha-pinene, beta-pinene, camphene and cineole, all of which are present in the Californian chaparral, from Tasmanian forest soil with which allelopathy has been associated. In Finland, Selander, Kalo, Kangas and Pertunnen (1974) carried out experiments in which the concentration of similar monoterpenes was shown to determine whether some species of insect were attracted or repelled by Pinus sylvestris L. (Scots pine). Franich, Gaskin, Wells and Zabkiewicz (1982) are among several groups of workers who have studied similar compounds in the context of toxicity of $P$. radiata D. Don (Monterey pine) and related coniferous species to fungi. In association with Pseudotsuga menziesii (Mirb.) Franco (Douglas fir) in Washington/Oregon, U.S.A., alpha-pinene has been shown to inhibit the growth of a variety of bacteria and a yeast (And rews, Parks \& Spence 1980)

Monoterpenes may also act in defence against vertebrates since Sheehy and Winward (1981), working in Oregon, found that 7 taxa of sage brush (Artemesia spp.) differed in their palatability to mule deer and domestic sheep. Artemesia spp. are high in monoterpenoids and further data showed that the concentration of alpha-pinene and an unidentified monoterpene accounted for $90 \%$ of the variation in mule deer utilization of various sage brush taxa. No doubt the increasing interest in the topic will reveal further ranges of defensive capability associated with particular chemicals.

A number of chemicals with defensive potential, including monoterpenoids, have been shown to be present in variable concentrations between 


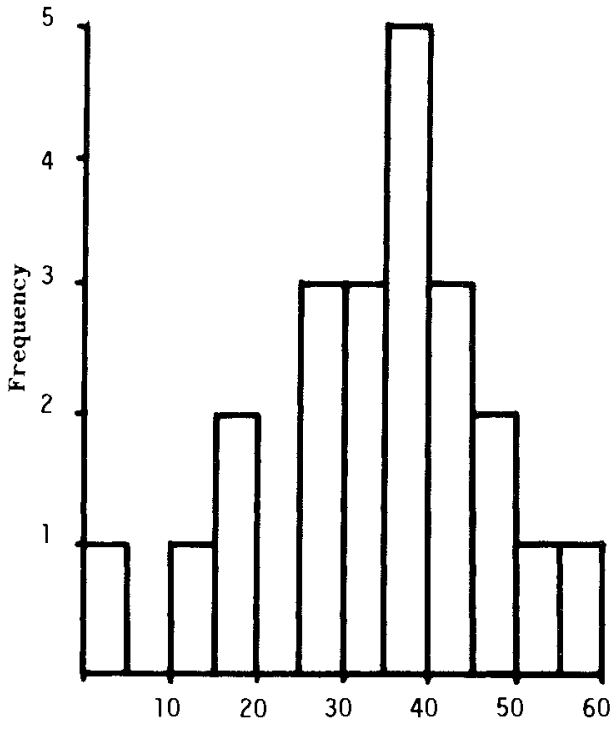

Reduction relative to control $(\%)$

FIG. 2 - Reduction in length of first seminal root of wheat in the seedling stage by washings of Salvia reflexa foliage

(means of 100 seedlings for each of 22 cultivars).

and within species. They may be under simple additive or polygenic control, as in the case of alkaloids in the Solanaceae (Mann \& Weybrew 1958; Levin \& York 1978). Further, cultivated species subjected to chemical interference also vary in their susceptibility (fig. 2). The possibility of selection for enhanced defensive capability in both 'active' and 'passive' modes, therefore, appears to exist and such selection might be used to the advantage of agriculture, forestry and horticulture.

\section{REFERENCES}

ANDREWS, R.E., PARKS, L.W. \& SPENCE, L.D. 1980: Some effects of Douglas fir terpenes on certain micro-organisms. Apl.Env. Micro., 40: $301-304$.

CLARK, R.J. \& MENARY, R.C., 1980: Environmental and cultural factors affecting the yield and composition of peppermint oil (Mentha piperita L.). VIIIth Int. Cong. Essential Oils, Cannes, October 1980. pp.74-79.

COGGER, H.G., 1979: REPTILES AND AMPHIBIANS OF AUSTRALIA. Reed, Syd ney.

CROMWELL, B,T., 1944: Studies on the synthesis of hyoscyamine in Atropa belladonna $\mathrm{L}$, and Datura stramonium L. Biochem. J. 37: 717 722 .
CUTTER, EG, 1976: Aspects of the structure and development of the aerial surface of higher plants. In DICKINSON, C.H. \& PREECE, T.F (Eds): MICROBIOLOGYOF AERIAL PLANT $S U R F A C E S$. Academic Press, Lond on, 1-40.

DAWSON, R.F., 1948: Alkaloid biogenesis. Adv. Enzym. 8: 203-251.

DONALD, C.M., 1963: Competiton among crop and pasture plants. Adv. Agron. 15: 1-118.

EDMUNDS, M., 1974: DEFENCE IN ANIMALS Longman, Harlow.

FAHN, A., 1967: PLANT ANATOMY. Pergamon Press, Oxford.

FELTON, W.L., 1979: The competitive effect of Datura species in five irrigated summer crops. Proc. VIlth Asian-Pacific Weed Sci. Soc. Conf., Sydney, November 1979. pp. 99-104.

FRANICH, RA, GASKIN, R.E, WELLS, LG \& ZABKIEWICZ, J.A., 1982: Effect of Pinus radiata needle monoterpenes on spore germination and mycelial gowth of Dothistroma pini in vitro in relation to mature tree resistance. Phys. Plant Path. 21: 55-63.

GOSLING, L.M., 1980: Defence guilds of savannah ungulates as a context for scent communication. Symp. zool. Soc. Lond. No. 45, 195-212.

GRÜMMER, G. \& BEYER, H., 1960: The influence exerted by species of Camelina on flax by means of toxic substances. In HARPER, J.L. (Ed.) THE BIOLOGY OF WEEDS. Blackwell, Oxford, 153-157.

HALL, J.L., FLOWERS, T.J. \& ROBERTS, R.M. 1982: PLANT CELL STRUCTURE AND $M E T A B O L I S M$. Longman, London. Second edition

HARPER, J.L., 1977: POPULATION BIOLOGY OF $P L A N T S$. Academic Press, Lond on.

HEWSON, H.J., 1982: Brassicaceae, In FLORA OF AUSTRALIA Vol. 8. Lecythidales to Batales. Australian Government Publishing Service, Canberra, pp.231-357.

JAMES, W.O., 1946: Demonstration of alkaloids in Solanaceous meristems. Nature 158: 377

LEVIN, D.A., 1973: The role of trichomes in plant defence. Quart. Rev. Biol., 48: 3-15.

LEVIN, D A 1976. The chemical defences of plants to pathogens and herbivores. Ann. Rev. Ecol Syst., 7: 121-159.

LEVIN, D.A.\& YORK. B.M., 1978: The toxicity of plant alkaloids: an ecogeographic perspective. Biochem. Syst. Ecol., 6: 61-76.

LEVITT, J.\& LOVETT, J.V., 1984: Activity of allelochemicals of Datura stramonium L. (Thornapple) in contrasting soil types. Plant and Soil, 79: $181-189$

LEVITT, J., LOVETT, J.V. \& GARLICK, P.R., 1984 Datura stramonium allelochemicals: longevity in soil and ultrastructural effects on root tip cells of Helianthus annuus L. New Phytol., 97 213-218.

LOVETT, J.V., 1979: The ecological significance of odour in weeds. Proc. VIIth Asian-Pacific Weed Sei. Soc, Conf., Sydney, November 1979 . pp.335-338. 
LOVETT, J.V., 1982a: Allelopathy and self-defence in plants. Aust. Weeds, 2: 33-36.

LOVETT, J.V., 1982b: The effects of allelochemicals on crop growth and development. In McLAREN, J.S.(Ed.): CHEMICAL MANIPULATIONOF CROP GROWTH AND DEVELOPMENT. Butterworths, Lond on, 93-110.

LOVETT, J.V., 1983a: Self-defence chemicals of plants. Proc. Xth Int. Congr. Plant Prot., Brighton, November, 1983, p.838.

LOVETT, J.V., 1983b: Allelopathy and weed management in cropping systems. Proc. IXth AsianPacilic Weed Sci. Soc. Conf., Manila, November $1983,31-46$

LOVETT, J.V \& DUFFIELD, A M, 1981. Allelochemicals of Camelina sativa J. Appl. Ecol. 18: 283-290.

LOVETT, JV \& JACKSON H F 1980: Allelopathic activity of Camelina sativa (L.) Crantz in relation to its phyllosphere bacteria. New Phytol., 86: $273-277$.

LOVETT, J.V.\& LEVITT, J., 1981: Allelochemicals in a future agriculture. In STONEHOUSE, B. (Ed.): BIOLOGICAL HUSBANDRY. Butterworths, Lond on, 169-180.

LOVETT, J.V. \& SAGAR, G.R., 1978: Influence of bacteria in the phyllosphere of Camelina sativa (L.) Crantz on germination of Linum usitatissimum L. New Phytol., 81: 617-625.

LOVETT, J.V., FRASER, S.A. \& DUFFIELD, A.M., 1982: Allelopathic activity of cultivated sunflowers. Proc. Tenth Int. Sunfl. Conf., Surfers Paradise, March 1982, 198-201.

LOVETT, J.V., LEVITT, J., DUFFIELD, A.M. \& SMITH, N.G., 1981: Allelopathic potential of Datura stramonium L. (Thorn-apple). Weed Res., 21: 165-170.

MANN, T.J \& WEYBREW J A 1958: Inheritance of alkaloids in hybrids bet ween flue-cured tobacco and related amphidiploids. Tob. Sci, , 2: 120-125.
MOLISCH, H., 1937: DER EINFLUSS EINER PFLANZE AUF DIE ANDERE-ALLELOPATHIE. Fischer, Jena.

MOTHES, K., 1955: Physiology of alkaloids. Ann. Rev. Pl. Physiol., 6: 393-442

MULLER, C.H., 1966: The role of chemical inhibition (allelopathy) in vegetational composition. Bull. Torr. Bot. Club , 93: 332-351.

PURDIE, R.W., SYMON, D.E. \& HAEGI, L., 1982 Solanaceae. In FLORA OF AUSTRALIA Vol 29. Australian Government Publishing Service, Canberra.

RABOTNOV, T.A., 1981: Importance of the evolutionary approach to the study of allelopathy. Soviet $J$ Ecol. 12: 127-130.

SELANDER, I, KALO, P. KANGAS, E \& PER TUNNEN, V., 1974: Olfactory behaviour of Hylobium abietis L. (Col., Curculionidae). Response to several terpenoid fractions isolated from Scots pine phloem. Ann. Entom. Fenn., 40 $108-115$.

SHEEHY, D.P. \& WINWARD, A.H., 1981: Relative palatability of seven Artemisia taxa to mule deer and sheep, J Range Mgmt. 34: 397-399.

TURSTON, R., SMITH, W.T. \& COOPER, B.P., 1966 Alkaloid secretion by trichomes of Nicotiano species and resistance to aphids. Ent. Exp. et App. 9: 428-432.

TRENBATH, B.R. \& FOX, L.R., 1976: Insect frass and leaves from Eucalyptus bicostata as germination inhibitors. Aust. Seed Sci. Newsl., 2: 34-39

WHITTAKER, R.H., 1970: The biochemical ecology of higher plants. In SONDHEIMER, E. \& SIMEONE, J.B. (Eds): CHEMICAL ECO $L O G Y$. Academic Press, New York, 43-70.

WILLIS, J.H., 1972: A HANDBOOK TO PLANTS IN VICTORIA. Vol. II. Dicotyledons. Melbourne University Press, Melbourne.

(accepted Jan. 15, 1985) 